\title{
RADIAL GROWTH DYNAMICS OF Khaya ivorensis TREES FROM EXPERIMENTAL PLANTATION ${ }^{1}$
}

Denise Ransolin Soranso ${ }^{2 *}$, Graziela Baptista Vidaurre ${ }^{3}$, Matheus Peres Chagas ${ }^{4}$, José Tarcísio da Silva Oliveira $^{3}$, João Gabriel Missia da Silva² and João Vicente de Figueiredo Latorraca ${ }^{5}$

\footnotetext{
${ }^{1}$ Received on 02.12.2016 accepted for publication on 23.01.2018.

${ }^{2}$ Universidade Federal do Espírito Santo, Programa de Pós-Graduação em Ciência Florestal, Jerônimo Monteiro, ES - Brasil. E-mail: <denise_soranso@hotmail.com>and<j.gabrielmissia@hotmail.com>.

${ }^{3}$ Universidade Federal do Espírito Santo, Centro de Ciência Florestais e da Madeira, Jerônimo Monteiro, ES - Brasil. Email:<grazividaurre@gmail.com>and<jtsilva@npd.ufes.br>.

${ }^{4}$ Universidade Federal de Goiás, Setor de Engenharia Florestal, Goiânia, GO - Brasil. E-mail: <mpchagas@gmail.com>.

${ }^{5}$ Universidade Federal Rural do Rio de Janeiro, Departamento de Produtos Florestais, Seropedica, RJ - Brasil. E-mail: <latorraca@hotmail.com>.

*Corresponding author.
}

\begin{abstract}
The objective of this study was to characterize the formation of growth rings in Khaya ivorensis wood, as well as to analyze the variation in the morphology of the vessel elements, aiming to understand the growth of this species in experimental plantations. Disks from the bases of five trees were collected, and after polishing the cross-section, demarcation of the growth rings limits was carried out. The anatomical study of the wood was conducted with the purpose of characterizing the rings, and their width was measured by means of scanned images of the disks. A historical series of data was obtained concerning the diameter of the trees to establish a correlation with the width of the rings measured over the years. The growth rings limits of African mahogany wood are demarcated by a thin layer of marginal parenchyma, and the presence of false rings has been observed. Significant annual growth correlation of 0.62 was observed among the trees, being the radial increment of irregular wood in the first years (wide and narrow rings), and highlighting the $3^{\text {rd }}$ and $11^{\text {th }}$ year of growth in which the largest increases were observed due to a biological adaptation tendency to the environment and the occurrence of thinning carried out in the planting area, respectively.
\end{abstract}

Keywords: African mahogany; Anatomic characterization; Radial growth.

\section{DINAMMICA DOS ANÉIS DE CRESCIMENTO DE ARVORES DE Khaya ivorensis PROVENIENTES DE PLANTIOS EXPERIMENTAIS}

\begin{abstract}
RESUMO - O presente trabalho teve como objetivo caracterizar a formação de anéis de crescimento no lenho de Khaya ivorensis, bem como, analisar a variação da morfologia dos elementos de vaso, visando ao entendimento do crescimento dessa espécie em plantios experimentais. Para tanto, discos da base de cinco árvores foram coletados e, após o polimento da seção transversal, realizou-se a demarcação dos limites dos anéis de crescimento. Um estudo anatômico da madeira foi realizado com objetivo de caracterizar os anéis e por meio de imagens digitalizadas dos discos foi mensurada a largura dos mesmos. Foi obtida uma série histórica de dados referente ao diâmetro das árvores para estabelecer uma correlação com a largura dos anéis mensurada ao longo dos anos. Os limites dos anéis de crescimento da madeira de mogno africano são demarcados por uma fina camada de parênquima marginal, tendo sido constatada a presença de falsos anéis. Foi observada entre as árvores correlação de crescimento anual significativa de 0,62, sendo o incremento radial do lenho irregular nos primeiros anos (anéis largos e estreitos), com destaque para o $3^{\circ}$ e o $11^{\circ}$ ano de crescimento, em que foram observados os maiores incrementos, devido a uma tendência biológica de adaptação ao ambiente e pela ocorrência de um desbaste realizado na área de plantio, respectivamente.
\end{abstract}

Palavras-Chave: Mogno africano; Caracterização anatômica; Crescimento radial. 


\section{INTRODUCTION}

Knowledge of the anatomical structure of wood is important for understanding the evolutions that occurred in the wood characteristics formed during the tree's life. Through the growth rings of wood, it is possible to verify factors that have contributed positively or negatively to its development in periods of full or scarce cambium activity.

The insertion of studying wood growth rings in characterizing tropical and subtropical tree species is something recent. Historically, there was no recognition of the formation of annual growth rings in these species until the first studies such as that of Worbes (1995). From this point of view, there has been an increase in the research focused on this area of knowledge (Dünisch et al., 2003; Andreacci et al., 2013; Lobão et al., 2016; Rosa et al., 2017; Pagotto et al., 2017).

The characterization of growth rings formation in wood has contributed to provide information on the ecology of tropical and subtropical forests, to guide forest management and conservation practices, and to assess the impacts of climate change on these forests (Rozendaal and Zuidema, 2011). Information on the growth of a species not only describes the potential for volume production of forests and the quality of the wood produced by it, but it also provides a valuable basis for understanding the interactions between trees and their environment (Spiecker, 2002).

In addition to the use of growth rings width values, other anatomical parameters such as conducting vessel morphology have been used as indicators of changes in the characteristics of the growth environment of trees (Lindorf, 1994; Giantomasi et al., 2009). As it is a biological material, wood exhibits great variation regarding the dimensions of the anatomical elements, and consequently their properties in the pith to bark direction and along the trunk. This variability can also be observed in the growth rings and influences the different physical-chemical and mechanical characteristics of the wood, which may imply different applications of the final product in terms of industrial use (Margarido et al., 2005).

Thus, the characterization of wood growth rings is important, mainly for generating information on the growth dynamics of trees because they allow better understanding of the sensitivity of the species in a

Revista Árvore. 2018;42(2):e420207 certain place for environmental changes, they help in the quality control of the wood and contribute to economic forest management (Spiecker, 2002; Santos et al., 2015).

In Brazil, many producers have invested in African mahogany plantations in order to meet the growing demand of wood for solid products. Khaya ivorensis A. Chev has been the African mahogany species most widely used in commercial planting (Silva et al., 2016). It is known that the wood of this species from native forests has a high price in the international market, being considered of high quality for furniture production and interior finishing, and can also be used in shipbuilding (Orwa et al., 2009).

Some studies on the characteristics and quality of the wood from this planted species have been published in Brazil (Carvalho et al., 2010; França et al., 2015; Silva et al., 2016; Soranso et al., 2016). However, there is a lack of information regarding its growth dynamics, since the commercial-scale plantations are mostly still under development in the country.

In the search for knowledge and development of the potentialities of Khaya ivorensis, it is important to carry out research on this species to evaluate its development in the growth situations for which it was imposed, aiming at subsidies for genetic improvement and silvicultural practices.

In this context, the present work aimed to characterize the formation of growth rings in the Khaya ivorensis wood, as well as to analyze the variation in the morphology of the vessel elements in aiming to understand the growth of this species in experimental plantations.

\section{MATERIALAND METHODS}

\subsection{Study area, sampling and preparation of material}

The material of this research came from an experimental planting of the Vale Natural Reserve located in the municipality of Linhares, north of Espírito Santo state, in the geographical coordinates ranging from $19^{\circ} 06^{\prime}$ to $19^{\circ} 18^{\prime}$ south latitude and meridians $39^{\circ} 45^{\prime}$ to $40^{\circ} 19^{\prime}$ west longitude (Datum WGS84). Planting with the seedlings started in the year 1993 with an initial spacing of $3 \times 2 \mathrm{~m}$ in an area of $0.15 \mathrm{ha}$. A thinning without technical criterium was carried out in the planting in 2003.

The soil of the area is predominantly yellow argisol and has a humid tropical climate (Aw) with rainy season in summer and dry in winter according to Köppen 
classification. The mean annual rainfall and temperature are $1200 \mathrm{~mm}$ and $25.08^{\circ} \mathrm{C}$, respectively.

For this study disks were collected from the base of five Khaya ivorensis trees (April 2012) selected based on the mean diameter, and disregarding the border trees. The disks were dried, then planed and the crosssection of the samples was then polished with a sanding sequence using a granulation from 60 up to 2000 grains/ $\mathrm{mm}^{2}$ for better visualization of the wood growth rings.

\subsection{Anatomical characterization of the growth rings}

A microscopic study of the wood was carried out in order to identify the anatomical characteristics in the growth rings limits of Khaya ivorensis, in accordance with the recommendations of the Comisíon Panamericana de Normas Técnicas (1974) and also the list of microscopic features for the identification of wood from the International Association of Wood Anatomists (1989).

The variation in the characteristics of the vessel elements of the direction from pith to bark was observed, since these help in verifying the radial growth dynamics. Its distribution, proportion and size are indicators of the cambium activity, which is important for identifying the presence of earlywood and latewood, thus facilitating differentiation of the growth ring. For this, specimens were removed from a single sample every $1.5 \mathrm{~cm}$, totaling nine positions along the radial profile of the wood with mapping of the growth rings, and with emphasis on the first, fifth, tenth, fifteenth, and eighteenth growth rings, as shown in Figure 1.

The anatomical parameters of the evaluated vessels were: tangential diameter and frequency. Anatomic sections (18-20 ìm thick) were taken from the crosssection of the samples and histological slides were assembled, which were then photomicrographed by a digital camera (7.1 mega pixel) coupled to an optical microscope and measurements were taken with image analysis software (Image-Pro Plus - version 4.5.0.29). Next, 20 measurements of the diameter (im) and frequency $\left(\mathrm{n} \mathrm{mm-}{ }^{2}\right)$ of the vessels were performed in each slide of the nine sampled regions.

\subsection{Chronological series and radial growth of the tree trunks}

Growth rings were identified and demarcated in four rays per disc with the aid of a stereoscopic microscope. Afterwards, the samples were scanned in a high resolution scanner for further measurement of the width of the growth rings by means of image analysis software.

The width series were constructed by measuring the width of the wood growth rings in the five trees,

* Ordinal numbers correspond to the position of the first, fifth, tenth, fifteenth, and eighteenth growth rings.

*Números ordinais correspondem a posição do primeiro, quinto, décimo, décimo quinto e décimo oitavo anel de crescimento.

\section{Positioning of the growth rings along the sample}

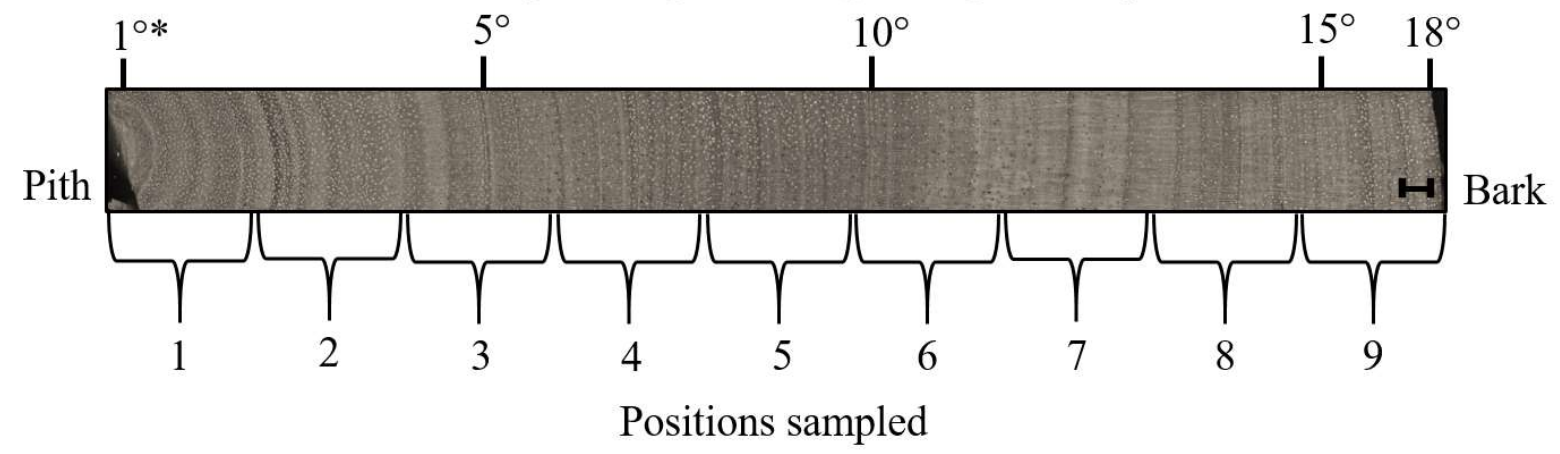

Figure 1 - Mapping of the specimens for morphological characterization of the vessel Khaya ivorensis, according to the pith to bark position. Bar corresponds to $2 \mathrm{~mm}$.

Figura 1 - Mapeamento da amostra para caracterização morfológica dos vasos de Khaya ivorensis, de acordo com a posição medula-casca. Barra corresponde a $2 \mathrm{~mm}$. 
and their synchronization was carried out using Cofecha software, which assists in the quality control of the series (Pearson correlation and t test at $5 \%$ significance) with the identification of a possible existence of false or absent growth rings (Speer, 1971).

In order to understand the growth dynamics of this species in experimental plantations, a historical series of data was obtained regarding the growth monitoring in diameter with bark of the trees at 1.30 meters of soil height (DAP), between the period of 1994 and 2011. With of these datas was determined of mean annual increment in diameter (IMAD) which consists in dividing the mean diameter by the corresponding age and the current annual increment in diameter (ICA), which refers to the growth occurred in a period of 12 months. The values of IMAD and ICA were subsequently related to the average growth ring width values from each year.

\section{RESULTS}

\subsection{Anatomical characterization of the growth rings}

The macro and microscopic cross-section of the wood growth rings of Khaya ivorensis trees (with emphasis on the zones delimiting the growth rings) are shown in Figure 2.

A)

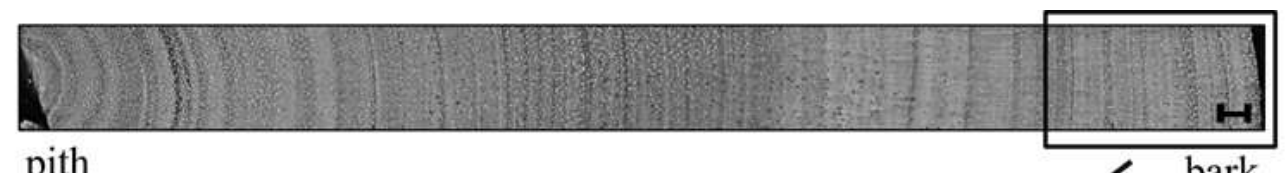

B)

pith

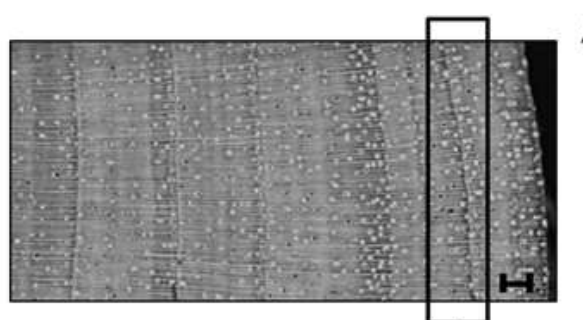

bark

C)

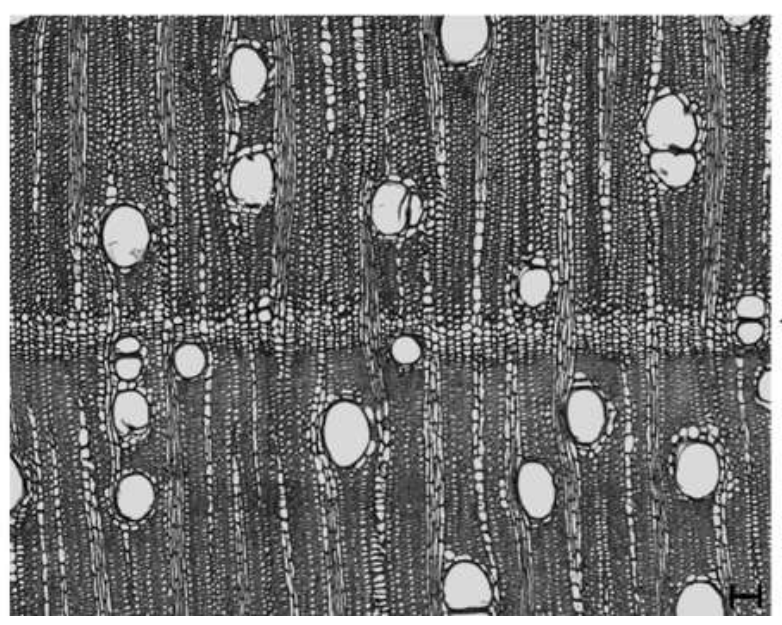

Marginal parenchyma delimiting the growth ring

Figure 2 - Wood characteristics of the Khaya ivorensis trees at 18 years old. Macroscopic (A and B) microscopic structure (C) showing a marginal parenchyma which delimits the growth rings. Bars in (A and B) correspond to $2 \mathrm{~mm}$ and in (C) corresponds to 100 ìm.

Figura 2 - Características do lenho das árvores de Khaya ivorensis, aos 18 anos de idade. Estrutura macroscópica (A e B) e microscópica (C) evidenciando o parênquima marginal que delimita a zona de um anel de crescimento. Barras em (A e B) correspondem a $2 \mathrm{~mm} \mathrm{e} \mathrm{em} \mathrm{(C)} \mathrm{corresponde} \mathrm{a} 100 \mathrm{im}$.

Revista Árvore. 2018;42(2):e420207 
Khaya ivorensis wood growth ring limits are generally easy to detect and are characterized by a thin layer of marginal parenchyma ( 3 to 7 cells), as observed in Figure 2C.

False rings were found in the wood in addition to the true annual growth rings. These are distinguished from true ones (Figure 3A and B) because they are not continuous along the circumference of the disks, alternating highly visible demarcation zones with others where the anatomical demarcation features do not exist (Figure 3C and D).

Absent growth rings were observed in the Khaya ivorensis wood, as these did not present a clear marking
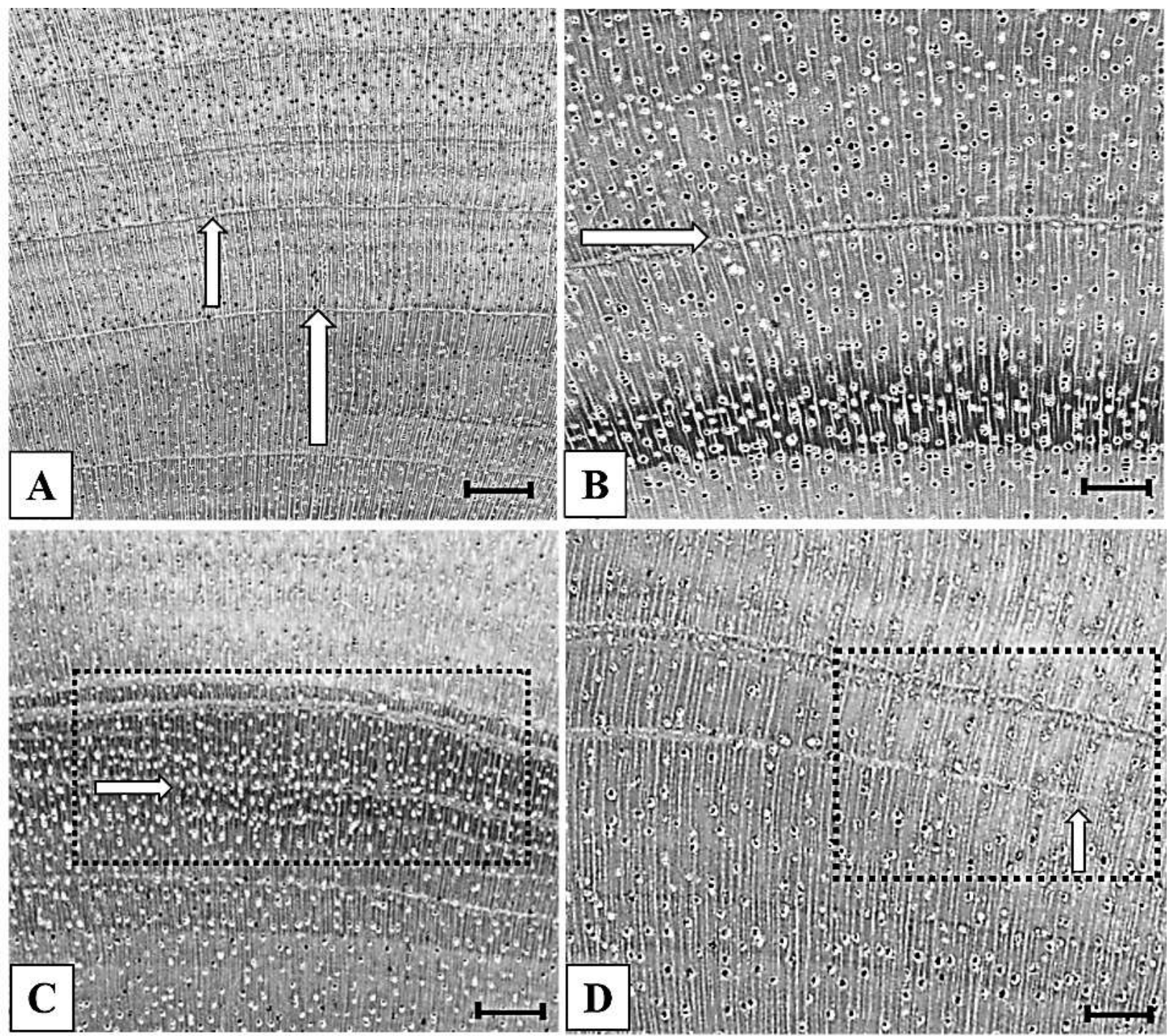

Figure 3 - Macroscopic cross-section of the Khaya ivorensis wood showing the limit of growth rings characterized by marginal parenchyma (A and B) and failure in continuity of the growth ring (false growth ring) (C and D). Arrows indicate the limit of true and false growth rings. Bars correspond to $2.0 \mathrm{~mm}$.

Figura 3 - Seção transversal macroscópica da madeira de Khaya ivorensis evidenciando o limite dos anéis de crescimento caracterizado pela presença de parênquima marginal ( $A$ e $B$ ) e falha na continuidade do anel de crescimento (falso anel de crescimento) (C e D). Setas indicam o limite dos anéis de crescimento verdadeiros e falsos. Barras correspondem a 2,0 $\mathrm{mm}$. 


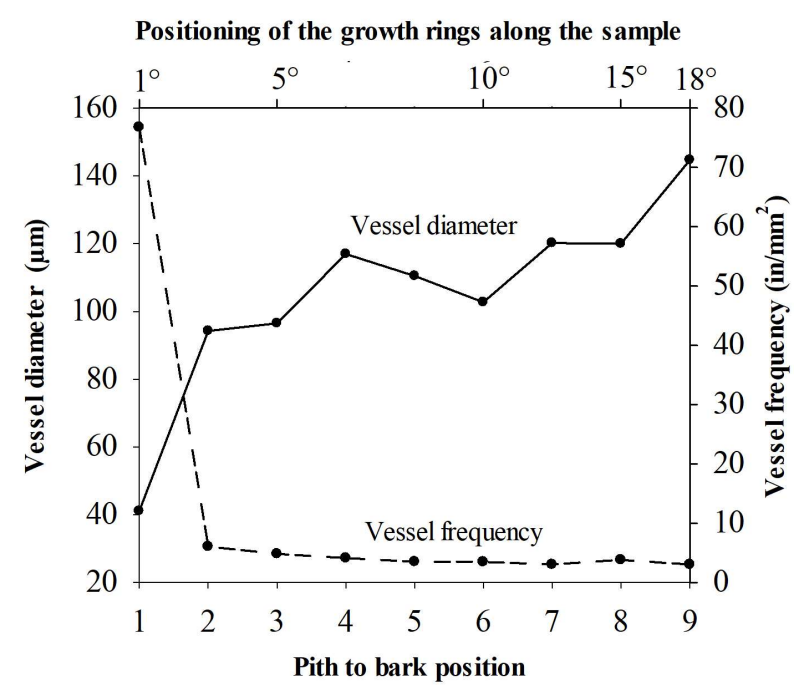

Figure 4-Morphology of Khaya ivorensis vessel elements at 18 years of age, according to the distribution of the rings by pith to bark position.

Figura 4-Morfologia dos elementos de vasos de Khaya ivorensis aos 18 anos de idade, conforme a distribuição dos anéis por posição medula-casca.

as in the other rings. Detection of the absent growth rings was possible due to synchronizing the growth between the evaluated trees, with the highest occurrence between the rings formed in 1999 and 2004.

In relation to the morphology of vessel elements, differences were observed between the pith to bark positions of the wood for the tangential diameter of the vessels, as observed in Figure 4. A higher vessel frequency $\left(\mathrm{in} / \mathrm{mm}^{2}\right.$ ) was observed in the radial position 1 (near the pith).

In the pith to bark direction, there was a considerable increasing tendency in the tangential diameter of the vessels, with stabilization in their frequency by disregarding the first position that covers the pith region. The vessel elements in the first growth rings tended to a smaller tangential diameter, which increased with advancing age.

\subsection{Chronological series and radial growth of the tree trunks}

The estimated age of the Khaya ivorensis trees was 18 years, being equivalent to the real age of the planting. Figure 5A shows the synchronism in the radial growth presented by the sampled trees.
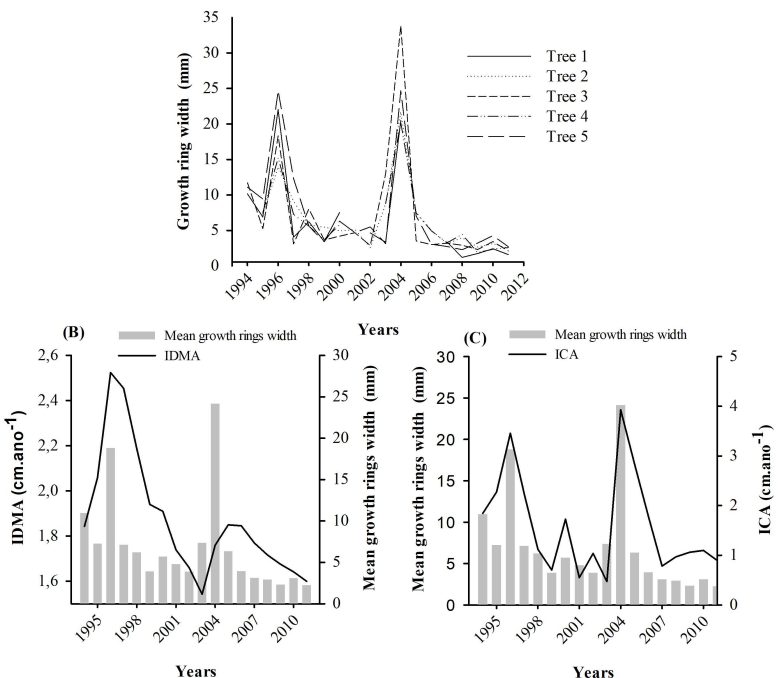

Figure 5 - Synchronization of growth ring width (A), mean annual increment in diameter (IMAD) of trees versus mean growth rings width of each year (B); current annual increment (ICA) of trees versus mean growth rings width of each year of the Khaya ivorensis tree at 18 years of age.

Figura 5-Sincronização da largura dos anéis de crescimento (A); incremento médio anual em diâmetro (IMAD) das árvores versus a largura média dos anéis de crescimento de cada ano (B); incremento corrente anual (ICA) das árvores versus a largura média dos anéis de crescimento de cada ano do tronco das árvores de Khaya ivorensis aos 18 anos de idade.

The radial growth of the five measured trees had a significant Pearson correlation of 0.62 , above the critical correlation value $(0.57)$, verifying that the width series of the growth rings showed a common sign of growth over the years.

The average width of the Khaya ivorensis wood growth rings was $6.93 \mathrm{~mm}$. There was an irregular growth (presence of wide and narrow rings) in the first 11 years tending to regular growth in the last seven years (presence of narrow rings). The rings formed in the years 1996 and 2004 had a mean width of $18.83 \mathrm{~mm}$ and $24.19 \mathrm{~mm}$, respectively, stand out due to the considerable increase, which is higher than the general average, as observed in Figure $5 \mathrm{~A}$ and $\mathrm{B}$.

There was an increase in the ring width formed in 2004 (year 10), corresponding to the year after the thinning in the plantation area. In the data analysis of mean annual increment in diameter (IMAD) and current

Revista Árvore. 2018;42(2):e420207 
annual increment in diameter (ICA) of the area, a considerable increase was observed in the values after the year 2003, which coincided with the consecutive year of 2004 in which the trees showed an abrupt increase in ring width (Figure 5B and C).

\section{DISCUSSION}

\subsection{Anatomical characterization of the growth rings}

According to IAWA classification (1989), the growth rings of Khay a ivorensis wood can be classified as type I, meaning with distinct demarcation limits due to the presence of marginal axial parenchyma, which is an anatomical character evident in the zones that delimit them.

The occurrence of demarcation zones in the growth rings of Khaya ivorensis is contrary to other authors (Lemmens, 2008; Rinne et al., 2011), who cited the absence of anatomical features that indicated a clear delineation zone among the growth rings of this species. This divergence in results may be related to seasonal characteristics of the growth region of the studied species. The authors (Chimelo, 1986; Botosso and Mattos, 2002; Fritts, 1976; Latorraca et al., 2015; Rozendaal and Zuidema, 2011), report that plants which grow in environments with intense climatic seasonality exhibit annual growth cycles, and can in turn form distinct growth rings. In regions where there are no well-defined seasons, the formed rings are indistinct or little evident, and do not correspond to the annual growth periods.

Even with the distinct presence of annual growth rings, the formation of false and absent growth rings was observed, especially in the first ten years of growth. According to Mattos et al. (2005), it is common to have discontinuous rings in tropical and subtropical trees which do not form a circumference around the pith, and even an absence of them. These can occur in the trees in response to different environmental influences such as prolonged periods of drought or rain and other climatic phenomena, which can contribute to temporary interruption in the cambium activity, thereby allowing for the formation of more than one growth ring in the year (Costa et al., 2006).

In relation to the vessel elements, as explained by Nisgoski et al. (2012), the increase in the tangential diameter in the pith to bark direction are characteristic aspects of plant development, such as an anatomical adaptation of the xylem to increase the volume of mineral sap, thus increasing its photosynthetic capacity.
In spite of the tendency to increase in the " 5 " and " 6 " radial positions sampled, a decrease in the tangential diameter of the vessels was observed (Figure 4). This decrease may be related to competition imposed between individuals. It is verified that after the thinning occurrence (at 10 years) there was a tendency of increasing vessel diameter in response to the decrease in competition.

\subsection{Chronological series and radial growth of the tree trunks}

Brown (2003) explained that when trees develop in similar conditions over time they tend to be compatible with growth rates, and especially those of the same species. With synchronism in the width variation of the growth rings (Figure 5A) formed by the trees, it is possible to determine the rings year of formation according to the calendar years.

For the present work this is a result of the fact that the evaluated trees come from an planting area in which the growth similarity tends to be greater when compared to an area of native forest, for example, because the trees were cultivated in a common period of time and under the same soil and climatic conditions and silvicultural interferences over the years.

For the Khaya ivorensis wood, it was observed that there were larger increases in the width of the growth rings in the years 1996 and 2004. The ring width formed in 1996 can be explained by the fact that there were broad growth rings formed in the early years due to the biological tendency of trees to adapt to the environment in which it was established, as well as a lack of competition between the individuals in the early growth years.

On the other hand, the ring corresponding to the year 2004 is associated to the occurrence of a thinning performed in the planting area. This in turn aims to stimulate the growth of the remaining trees and increase their production, as explained by Lima and Garcia (2010).

By analysing the mean annual increment in diameter (IMAD) and the current annual increment (ICA) of the tree trunks, a considerable increase in the growth ring width corresponding to the year 2004 subsequent to the thinning was observed (Figure $5 \mathrm{~B}$ ). This high rate of radial increase is mainly associated with the decrease in competition for light and nutrients among the individuals of that stand. This fact contributes 
to a favorable growth period, inducing the formation of large growth rings in relation to the others, as explained by Ferreira-Fedelle et al. (2004).

In addition, Medeiros et al. (2008) reported that when environmental variables change, they are recorded in the distinct growth rings, which express events in remote and contemporary times, are translated into tree growth, and ring width.

\section{CONCLUSIONS}

The growth layers of the Khaya ivorensis wood cultivated in a homogeneous plantation system in Brazil are delimited by the presence of marginal axial parenchyma. However, they do not always correspond to an annual periodicity.

The vascular frequency was similar between positions 2 to 9 , except for the first position corresponding to the pith region that provided higher frequency values. Regarding the tangential diameter of the vessel elements, there was a considerable tendency to increase as age increased.

Growth rings width series showed a common growth sign for the Khaya ivorensis species cultivated in experimental planting over the years. It was evidenced that thinning directly influenced the increase of the radial growth of all the trees in the year subsequent to its accomplishment.

\section{ACKOWLEDGMENTS}

To the Wood Quality Laboratory of UFES, the Vale Natural Reserve for the supply of material for this study, the forestry technician Jonacir Souza, the forestry engineer Gilberto Terra and the Foundation for the Support of Research and Innovation of Espírito Santo - FAPES for financing the research project and for the master's degree scholarship.

\section{REFERENCES}

Andreacci F, Botosso PC, Galvão F. Sinais climáticos em anéis de crescimento de Cedrela fissilis em diferentes tipologias de florestas ombrófilas do Sul do Brasil. Floresta. 2013;44(2):323-32. http:// dx.doi.org/10.5380/rf.v44i2.27316.

Botosso PC, Mattos PP. Conhecer a idade das árvores: importância e aplicação. Colombo: Embrapa Florestas; 2002. (Série Documentos; no. 75).
Brown PM. Introduction to dendrochronology lecture 1: basic terminology and concepts. Tucson: Rocky Mountain Tree-ring Research; 2003. p. 21.

Carvalho AM, Silva BTB, Latorraca JVF. Avaliação da usinagem e caracterização das propriedades físicas da madeira de mogno africano (Khaya ivorensis A. Chev.). Cerne. 2010;16(Suppl):106-14.

Chimelo JP. Anatomia da madeira. In: Lepage ES, editor. Manual de preservação de madeiras. São Paulo: IPT/SICCT; 1986. p. 41-67. vol. 1, no. 1637, cap. 3 .

Comisíon Panamericana de Normas Técnicas. Descripción de características generales, macroscópicas de las maderas angiospermas dicotiledóneas. Buenos Aires: COPANT; 1974. p. 1-19. vol. 30.

Costa CG, Callado CH, Coradin VTR, CarmelloGuerreiro SM. Xilema. In: Apezzato-da-Glória B, Carmello-Guerreiro SM. Anatomia vegetal. 2. ed. Viçosa: UFV; 2006. p. 129-154.

Dünisch O, Montóia VR, Bauch J. Dendroecological investigations on Swietenia macrophylla King and Cedrela odorata L. (Meliaceae) in the central Amazon. Trees. 2003;17(3):244-50.

Ferreira-Fedelle L, Tomazello M Fo, Botosso PC, Giannotti E. Periodicidade de crescimento de Esenbeckia leiocarpa Engl. (Guarantã) em duas áreas da região Sudeste do Estado de São Paulo. Sci For. 2004;(65):141-9.

França TSFA, Arantes MDC, Paes JB, Vidaurre GB, Oliveira JTS, Baraúna EEP. Características anatômicas e propriedades físico-mecânicas das madeiras de duas espécies de mogno africano. Cerne. 2015;21(4):633-40. http://dx.doi.org/10.1590/ 01047760201521041877.

Fritts HC. Tree rings and climate. California: Academic Press; 1976. 567 p.

Giantomasi MA, Juñent FAR, Villagra PE, Srur AM. Annual variation and influence of climate on the ring width and wood hydrosystem of Prosopis flexuosa DC trees using image analysis. Tress. 2009;23(1):117-26. http://dx.doi.org/10.1007/ s00468-008-0260-5.

Revista Árvore. 2018;42(2):e420207 
International Association Of Wood Anatomists. List of macroscopic features for hardwood identification. IAWA Bull. 1989;10(3):219-332.

Latorraca JVF, Souza MT, Silva LDSAB, Ramos LMA. Dendrocronologia de árvores de Schizolobium parahyba (Vell.) S. F. Blake de ocorrência na rebio de Tinguá-RJ. Rev Arvore. 2015;39(2):385-94. http://dx.doi.org/10.1590/010067622015000200018 .

Lemmens RHMJ. Khaya ivorensis A. Chev. In: Louppe D, Oteng-Amoako AA, Brink M, editors. Prota 7 (1): Timbers / Bois 1. Wageningen: PROTA; 2008. CD- ROM [cited 2015 Feb 7]. Available from: http://database.prota.org/ PROTAhtml/Khaya\%20ivorensis_En.htm

Lima IL, Garcia JN. Variação da densidade aparente e resistência à compressão paralela às fibras em função da intensidade de desbaste, adubação e posição radial em Eucalyptus grandis Hill ex-Maiden. Rev Arvore. 2010;34(3):551-9. http://dx.doi.org/10.1590/S0100-67622010000300019.

Lindorf H. Eco-anatomical wood features of species from a very dry tropical forest. IAWA J. 1994;15(4):361-76. http://dx.doi.org/10.1163/ 22941932-90001370.

Lobão MS, Ortega GP, Amaral E, Amorim PGR, Amaro MA, Roig FA, et al. Análise de similaridade das árvores de Cedrela sp. sob diferentes condições de crescimento no leste do estado do Acre, Brasil. Sci For. 2016;44(109):231-9. http://dx.doi.org/10.18671/scifor.v44n109.22.

Margarido M, Pinto I, Preira H, Usenius A, Anjos O. Caracterização da variação da espessura dos anéis de crescimento em Pinheiro Bravo. In: Actas das Comunicações $5^{\circ}$ Congresso Florestal Nacional; 2005; Viseu. Sociedade Portuguesa de Ciências Florestais; 2005. 12 p. [cited 2014 Ago 24]. Available from: https://www.repository.utl.pt/ handle/10400.5/667

Mattos PP, Seitz RA, Salis SM. Idade e ritmo de crescimento do tronco de árvores de espécies da floresta natural do pantanal matogrossense, MS. Pesqui Florest Bras. 2005;(50):69-80.

Medeiros JGS, Tomazello M Fo, Krug FJ, Vives AES Tree-ring characterization of Araucaria columnaris Hook and its applicability as a lead indicator in environmental monitoring. Dendrochronologia. 2008;26(3):165-71. http:// dx.doi.org/10.1016/j.dendro.2008.07.002.

Nisgoski S, Trianoski R, Muñiz GIB, Matos JLM, Stygar M. Variação radial das estruturas da madeira de Acrocarpus fraxinifolius Wight \& Arn. Floresta Ambient. 2012;19(3):316-24. http:// dx.doi.org/10.4322/floram.2012.037.

Orwa C, Mutua A, Kindt R, Jamnadass R, Anthony S. Agroforestree Database: a tree reference and selection guide version 4.0. Kenya: World Agroforestry Centre; 2009 [cited 2014 Ago 15]. Available from: http://

www.worldagroforestry.org/treedb/AFTPDFS/ Cordia_dichotoma.pdf

Pagotto MA, Desoto L, Carvalho A, Nabais C, Tomazello M Fo, Ribeiro A, et al. Evaluation of Xray densitometry to identify tree-ring boundaries of two deciduous species from semi-arid forests in Brazil. Dendrochronologia. 2017;42:94-103. http://dx.doi.org/10.1016/j.dendro.2017.01.007.

Rinne E, Hakkarainen J, Rikkinen J. Comparative ecological wood anatomy of African mahogany Khaya ivorensis with special reference to damage caused by Hypsipyla robusta. Eur Sci Res. 2011;51(1):265-70.

Rosa SA, Barbosa ACMC, Junk WJ, Da Cunha CN, Piedade MTF, Scabin AB, et al. Growth models based on tree-ring data for the Neotropical tree species Calophyllum brasiliense across different Brazilian wetlands: implications for conservation and management. Trees. 2017;31(2):729-42. http:// dx.doi.org/10.1007/s00468-016-1503-5.

Rozendaal DMA, Zuidema PA. Dendroecology in the tropics: a review. Trees. 2011;25(1):3-16. http:/ /dx.doi.org/10.1007/s00468-010-0480-3.

Santos AT, Mattos PP, Braz EM, Rosot NC. Determinação da época de desbaste pela análise dendrocronológica e morfométrica de Ocotea porosa (Nees \& Mart.) Barroso em povoamento. Cienc Florest. 2015;25(3):699-709. http://dx.doi.org/ $10.5902 / 1980509819620$.

Silva JGM, Vidaurre GB, Arantes MDC, Batista DC, Soranso DR, Billo DF. Qualidade da madeira 
de mogno africano para a produção de serrados. Sci For. 2016;44(109):181-90. http://dx.doi.org/ 10.18671/scifor.v44n109.18.

Soranso DR, Vidaurre GB, Oliveira JTS, Tomazello M, Silva JGM, Arantes MDC. Variabilidade física e anatômica da madeira de Khaya ivorensis A.

Chev. em diferentes espaçamentos de plantio. Sci For. 2016;44(110):519-26. http://dx.doi.org/ $10.18671 /$ scifor.v44n110.24
Speer JH. Fundamentals of tree-ring research. Tucson: The University Arizona Press; 1971. 333 p.

Spiecker H. Tree rings and forest management in Europe. Dendrochronologia. 2002;20(1-2):191-202. http://dx.doi.org/10.1078/1125-7865-00016.

Worbes M. How to measure growth dynamics in tropical trees. IAWA J. 1995;16(4):337-51. http:// dx.doi.org/10.1163/22941932-90001424.

Revista Árvore. 2018;42(2):e420207 